\title{
Witches which never flew: Native witchcraft and the cunning woman on the stage
}

\author{
Shokhan Rasool Ahmed \\ English Department, University of Sulaimani, Sulaimani-Kurdistan, Iraq \\ Email address: \\ shokhan_rasul@yahoo.com
}

To cite this article:

Shokhan Rasool Ahmed. Witches which Never Flew: Native Witchcraft and the Cunning Woman on the Stage. International Journal of Literature and Arts. Vol. 2, No. 5, 2014, pp. 130-141. doi: 10.11648/j.ijla.20140205.11

\begin{abstract}
In early modern England cunning men and women (often older people on the fringes of society) became easy targets for gossip within rural communities. I will examine some figures of the cunning woman in this period and show how they appear in different senses: the cunning woman as a healer, nurturer, fortune-teller and domestic manager. Mother Sawyer, in The Witch of Edmonton by William Rowley, Thomas Dekker and John Ford (1621), complains of the community of Edmonton that she has been convicted because she is 'poor, deform'd, and ignorant' (II.i.3). ${ }^{1}$ Sawyer has been abused because she is old and ugly and does not have any means by which to make her living. She is physically portrayed as a contemporary English witch. However Sawyer is not a witch from the beginning of the play, and not presented as one until her community accuse her of witchcraft. After she realizes that there is nothing left to lose, she makes a pact with the devil and thus her identity changes from an old woman into a real witch. In John Lyly's Mother Bombie (1594), Bombie is a 'white witch' or 'cunning woman' whose mysterious power is used to help people, not to harm. In Thomas Heywood's The Wise Woman of Hogsdon (1604), the Wise Woman pretends to be a cunning woman and skilled in fortune-telling, palmistry and curing diseases. The three protagonists in the mentioned plays are drawn from English witch-lore, and they live in the suburbs and resort to witchcraft in order to make their living. Mother Sawyer, a traditional English witch, is portrayed as hag-like whereas Mother Bombie and the Wise Woman are English local cunning women. The witches do not fly and stage directions do not call for flight in the witch scenes; their feet remain firmly on the ground in all scenes. Cunning women are not the same as witches: they do not have a familiar, they tell fortunes and cure diseases, are benevolent, they do not hold covens on the Sabbath, do not make pacts with the devil in return for rewards and they do not act maleficium. The chronological approach taken here is used in order to determine the dramatic development of the witches and cunning women in two theatrical modes - the tragic (The Witch of Edmonton) and the comic (Mother Bombie, and The Wise Woman of Hogsdon).
\end{abstract}

Keywords: Stage Directions and Genre, The Witch of Edmonton, Mother Bombie, and The Wise Woman of Hogsdon

\section{Introduction}

Before I discuss why this paper is about native witchcraft and especially the cunning woman, I want to address the most important differences between English and Continental witches. 'Familiars' or 'imps', the servants of the witches who carry out their commands, are mentioned more often in the earliest English accounts. English witches are less sociable and more solitary compared with those of the Continental tradition; Continental witches meet in covens on the Sabbath, but there is little evidence for

\footnotetext{
${ }^{1}$ Thomas Dekker, John Ford, William Rowley, The Witch of Edmonton (1658), p. 14.
}

witches' Sabbaths in English witch trials. Dancing and feasting are also related to Continental witches. Sexual contact with demons (fornication with the devil) is related to Continental witches rather than English. However, there are English witches who make pacts with the devil (for example, Mother Sawyer). Although English witches are generally non-diabolical, the act of 'sucking' a witch's teat by an imp is mentioned more often in the English witchcraft accounts. Magic ointment and flying are Continental witch-beliefs when witches fly in the air or ride a broom. The belief that witches can transform into a hare or a cat is more a feature of the English witchcraft tradition, as is the belief that witches have control over the weather and raise storms. Forming pictures of their intended enemy 
from clay or wax belongs to the Scottish tradition of witchcraft and this was also practised in England: when witches throw their picture on the fire, then the intended victim gets ill or dies. ${ }^{2}$

This paper deals with native witches and 'cunning women' on stage and also considers why elderly women in early modern England were more prone to accusations of witchcraft than the young, and why a number of harmless women were tortured, including midwives and healers.

\section{The Witch of Edmonton by William Rowley, Thomas Dekker and John Ford (1621)}

The title page of The Witch of Edmonton shows that the play was published in 1658 and written by multiple authors: 'The Witch of Edmonton: A known true Story. Composed into a tragi-comedy by divers well-esteemed Poets; William Rowley, Thomas Dekker, John Ford, \&c. Acted by the Princes Servants, often at Court, with singular Applause'. ${ }^{3}$ There is a record of its performance at Court in December 1621 during the Christmas festivities. The quarto was entered in the Stationer's Register on 21 May 1658 by Edward Blackmore: Entred for his Copie (vnder $y^{\mathrm{e}}$ hand of $\mathrm{M}^{\mathrm{r}}$ Thomason Warden) a book called The Witch of Edmonton a TragiComedy by Will: Rowley \&c'. ${ }^{4}$ The 1658 Quarto does not seem to come from the theatre in the possession of an actor. In other words, 'it was not prompt copy but instead autograph papers or a rather literal scribal copy preliminary to the prompt book'. ${ }^{5}$ The Witch of Edmonton draws upon a pamphlet The Wonderful Discovery of E. Sawyer, a Witch which describes the late execution of Elizabeth Sawyer of Edmonton (she was hanged as a witch at Tyburn on April 19, 1621) ${ }^{6}$ and the belief in witchcraft in general and maleficium. The play seems to have been performed later in the same year the event occurred.

In terms of authorship, the title page might suggest that there are more than three authors. Besides the three poets mentioned here, other writers, whose reputation would not have increased the popularity of the play, may have participated in composition, as et cetera was written after

\footnotetext{
${ }^{2}$ See Keith Thomas, Religion and The Decline of Magic: Studies in Popular Beliefs in Sixteenth and Seventeenth-Century England (London: Penguin, 1971) p. $(568,679)$; James Sharpe, 'The Debate on Witchcraft', in A Companion to English Renaissance Literature and Culture, ed. by Michael Hattaway (Oxford: Blackwell, 2003), pp. 653-661 (p. 656), and Ronald C. Sawyer, 'Strangely Handled in All Her Lyms': Witchcraft and Healing in Jacobean England', Journal of Social History, 22 (1989), 461-485 (p. 461).

${ }^{3}$ Thomas Dekker, John Ford, William Rowley, The Witch of Edmonton, title page.

${ }^{4}$ Thomas Dekker, The Dramatic Works of Thomas Dekker, ed. by Fredson Bowers (Cambridge: The Syndics of the Cambridge University Press, 1958), iii, p. 483.

${ }^{5}$ Ibid., p. 485

${ }^{6}$ Thomas Dekker, The Witch of Edmonton: A Critical Editions, ed. by Etta Soiref Onat (New York: Garland Pub, 1980), p. 273.
}

the name of the three playwrights. However, Gifford suggests that William Rowley may not even be one of the team but his name had been added by the publisher as a trick of the trade 'to accumulate a number of names in the title-page, to catch as many readers as possible; and Rowley's was deservedly a very marketable name'. ${ }^{7}$ Both Dekker and Rowley were poets of considerable reputation in their day. Gifford is right that Rowley's name was popular at the time the play was published but this does not mean that he does not have a partial authorship in its composition. Indeed, most critics agree that Rowley had a hand in writing the play. Weber concludes that the scene between Frank, Susan, and Winnifride are from Ford's hand. The scenes of the intercourse of Mother Sawyer and her diabolical familiar seem to be in Dekker's style; and the scenes of Cuddy Banks and the Morris-dancers are from Rowley's hand. ${ }^{8}$ Here I will mostly investigate the scenes which were written by Dekker. It is thought that Dekker had a hand in writing Elizabeth Sawyer's scenes in the play.

The Witch of Edmonton, with Middleton's The Witch, as a contemporary English witch play was written when witch mania in England was increasing and witches enjoyed great popularity on stage. The play has two main plots. In the first, Frank Thorny, a young servant, secretly marries the pregnant Winifred, his fellow servant. However, her employer, Sir Arthur Clarington, takes advantage of Winifred. Frank's father wants his son to marry Susan, the daughter of a rich farmer, Old Carter, in order to solve his own financial woes. At the end, Frank runs away with Winifred, who is disguised as a man, and abandons Susan. Susan follows him but he stabs her. Finally, Frank is executed for his crime. In the second story, Elizabeth Sawyer, the 'witch' of Edmonton, makes a pact with the devil. The devil appears to Sawyer in the shape of a black dog (performed by a human actor) and sucks her blood in return for rewards. Her dog's name is Tom and only Sawyer and Cuddy Banks (the clown) can see him. Mother Sawyer is also executed for using witchcraft against her neighbours to kill their livestock and spoil their crops.

Through the role of Sawyer, Dekker portrays the poor condition of witches and shows how they were thought to live in sordid poverty in contrast to the wealth of the (male) sorcerer. Sawyer acts as a village witch who does real harm. In The Witch of Edmonton, unusually the dramatists stress the popular belief of witchcraft through the conversation of the three dancers involved in the morris dancing:

YOUNG BANKS. (...) Have we e'er a Witch in the Morice?

FIRST DANCER. No, no; no woman's part but Maidmarian and the hobby-horse.

YOUNG BANK. I'll have a Witch. I love a Witch.

FIRST DANCER. 'faith, Witches themselves are so

\footnotetext{
${ }^{7}$ John Ford, The Dramatic Works of John Ford: in two volumes, with notes critical and explanatory, ed. by William Gifford, 2 vols (London, 1827), ii, pp. 557-558.

${ }^{8}$ John Ford, The Dramatic Works of John Ford: with an introduction and explanatory notes, ed. by Henry Weber (London, 1811), i, pp. xii-xiv, ii, p. 399.
} 
common now adays, that the counterfeit will not be regarded. They say we have three or four in Edmonton besides, Mother Sawyer.

SECOND DANCER. I would she would dance her part with us. (III.i.5-11) ${ }^{9}$

The first Dancer's joke about their ubiquity in English society may also be a witty allusion to their 'common' appearance on the English stage. The second Dancer's wish that Sawyer would dance with them seems to be a sexual innuendo (of the kind that, as we have seen, is often made in reference to contact with witches), in spite of Sawyer's advanced age, and dancing and feasting are two of the practises associated with witches. Sawyer is convicted by her community because she is poor and deformed, and she has also only one eye: 'Bless us, Cuddy, and let her curse her tother eye out. What dost now' (II.i.89-90); she also does not have anything to warm herself up, instead sometimes she must: 'Gather a few rotten sticks to warm me' (II.i.21). In many of the plays I have discussed in this thesis, witches are depicted as both physically repulsive and, simultaneously, as the objects of lust (presumably because they are sexually available); the witch here is depicted as someone poor, old, and deformed. The play may be seen not only to capitalize on the recent execution of Elizabeth Sawyer in Edmonton, but also to suggest the consequences of the social and economic abuses of vulnerable people, which are seen as the cause of women becoming witches. The play also condemns the English witch trials which depended on the evidence of the neighbours rather than on the witches' confessions (as in the Continental witch trials). Witcheraft accusations and prosecutions served to support the politics of patriarchy in early modern England.

The Witch of Edmonton includes another witch practice that is rooted in English popular beliefs, namely that the witches have a teat. A teat is a witch mark which is made in Elizabeth's body by her familiar, the devil in the shape of dog, by sucking her blood. Reginald Scot claims that 'the Divell giveth to everie novice a marke, either with his teeth or with his clawis'. ${ }^{10}$ Sawyer is characterized as an alleged witch through her physical mark that her familiar sucked, found under her arm, as well as her act of maleficium (laming and killing children, blighting stocks and crops). Diane Purkiss points out that the shifting colour of the dog (Mother Sawyer's familiar, Tom), in The Witch of Edmonton, points to its unreliability and deceptiveness, signifying the instability of identity which is also 'emphasized by his curiously lengthy explanation of how he comes by bodies to use'. ${ }^{11}$ The dog's body is seen to be used for deceit and ill-will since he equates himself with the devil theatrically:

I'll shug in, and get a noble countenance;

Serve some Briarean footcloth-strider

\footnotetext{
9 Dekker, Ford, Rowley, The Witch of Edmonton (1658), p. 26.

${ }^{10}$ Reginald Scot, Discoverie of Witchcraft (London, 1654), book III, chapter 3.

11 Diane Purkiss, The Witch in History: Early Modern and twentieth-Century Representations (London and New York: Routledge, 1996), p. 246.
}

That has an hundred hands to catch at bribes,

But not a finger's nail of charity (V.i.183-6)

In English witch lore, the concept of having a familiar, such as toads, cats, frogs and others, to serve witches or magicians was common in English witchcraft, and at trials witches were accused of being served by familiars. ${ }^{12}$ The alleged witches were supposed to use their familiar's body for deceit and as a means of revenge and malice. Ashley calls Sawyer's pact 'malice for malice, the victim of the community turning upon it to wreak retaliation'. ${ }^{13}$ The devil-dog appeared as a result of Sawyer's desire for revenge: 'Ho! Have I found thee cursing? Now thou art mine own' (II.i.121). Elizabeth Sawyer desires revenge but at the same time she is afraid of giving up her soul. Therefore, she only agrees to make the pact with Devil after the Devil threatens to tear her into a thousand pieces. The dog sucks Sawyer's blood via her arm in return for rewards. Sawyer is still seen as malevolent although the evil acts are carried out by the Dog once he kills the cattle of Old Banks by blighting the corn. The dog becomes Sawyer's familiar once she has made a pact with him by selling her soul and body. However by the end of the play Sawyer curses him as she realizes that the dog does not obey her: 'Out Witch! Thy tryal is at hand: / Our prey being had, the Devil does laughing stand' (V.i.75-76). This indicates more of Sawyer's anger when she is deserted by the dog.

One can draw a comparison between Elizabeth Sawyer's misapprehensions about her relationship with the dog and the situation of Doctor Faustus. Sawyer's dog, Tom, is similar to Doctor Faustus' Mephistopheles. Both familiars appear in the shape of a Devil for Sawyer and Faustus. Having a familiar like Tom is related to English witchcraft, but the pact Sawyer makes here with the dog is a feature of Continental witchcraft. Atkinson points out that repentance for Sawyer might still be possible because 'Faustus, although he has similarly sealed with his blood a pact with the Devil, is urged until the very last moment to repent and be saved'. ${ }^{14} \mathrm{He}$ further finds that there is no doubt in Sawyer's ultimate fate: as 'she goes to her execution there is none of the forgiveness and reconciliation that accompany Frank and nobody expresses the conviction that she will achieve salvation'. ${ }^{15}$ However, Sawyer repents and condemns the Devil. An old man urges Doctor Faustus to repent which Faustus rejects, but no one urges Sawyer to repent. Finally, Mother Sawyer leaves the stage with difficulty and professes a new feeling of goodness in her repentance:

\footnotetext{
${ }^{12}$ Peter Corbin and Douglas Sedge, Three Jacobean Witchcraft Plays: The Tragedy of Sophonisba, The Witch, and The Witch of Edmonton (Manchester \& New York: Manchester University Press, 1986), p. 23.

${ }^{13}$ Leonard R.N. Ashley, review of 'The Witch of Edmonton: A Critical Edition. Renaissance Drama Series', ed. by Etta Soiref Onat and Stephen Orgel, Bibliotheque d'humanisme et Renaissance, 2 (1982), 476-479 (p. 478).

${ }^{14}$ David Atkinson, 'Moral Knowledge and the Double Action in The Witch of Edmonton', Studies in English Literature, 25 (1985), 419-437 (p. 432). ${ }^{15}$ Ibid., p. 462.
} 
These Dogs will mad me: I was well resolv'd

To die in my repentance; though 'tis true,

I would live longer if I might; yet since

I cannot, pray torment me not; my conscience

Is setled as it shall be: all take heed

How they believe the Devil, at last hee'l cheat you.

OLD CARTER, Tha'dst best confess all truly.

SAWYER, Yet again?

Have I scarce breath enough to say my Prayers? And would you force me to spend that in bawling?

Bear witness, I repent all former evil;

There is no damned Conjurer like the Devil. (Viii.41-51)

Faustus as a magician gains power by selling his blood to the Devil but in return, he has to pay the penalty for his bargain in a horrible death by the end of the play. Faustus's devilish contract is for the delight of power and knowledge, whereas Sawyer's contract with the devil is also for power to take revenge and work malice. Sawyer can be seen as malevolent since she takes revenge upon Old Banks and this happens as a result of her aggravation and evilness. If one looks at the social hierarchy of the play, Sir Arthur Clarington has the top position but countrymen and peasants occupy the middle, and the lower position is given to the witch, Elizabeth Sawyer, who had been feared and abused by her neighbours. Mother Sawyer's life is imagined by Dekker to be spent in a condition of sordid poverty. Similarly, Lyly's Mother Bombie and Heywood's Wise Woman are low-class figures, and serve their neighbours and relatives to make their living.

In The Witch of Edmonton, Elizabeth Sawyer's evil power blurs the borderlines between human, witch, and animal, her suckling familiar:

I have heard old Beldams

Talk of Familiars in the shape of Mice,

Rats, Ferrets, Weasels, and I wot not what,

That have appeared, and sucked, some say, their blood (II.i.102-5)

Then she calls her enemies sucking animals, when she says

this black cur

That barks and bites, and sucks the very blood

of me and of my credit (II.i.111-113)

Sawyer, as a witch, is depicted as a frightening female form through her tongue and her body. Young Cuddy Bab blames Tom for his wicked behaviour: 'to creep under an old witch's coats and suck like a great puppy! Fie upon't! I have heard beastly things of you, Tom' (V.i.173-174). Here the female body has been used in the context of anxieties surrounding the lactating body of the woman as a witch. Holmes gives the reason for the preponderant numbers of women who were accused of witchcraft because they were 'the weaker sex, more easily seduced by satanic temptation. But the machinery in which they became involved, often at the instigation of men, was created, controlled, and ultimately discarded by the magisterial and clerical elite'. ${ }^{16}$

\footnotetext{
${ }^{16}$ Clive Holmes, 'Women: Witnesses and Witches', Past \& Present, 140 (1993),
}

King James in his Daemonologie concentrated on the reason for the predominance of female witches and he asked what can be the cause that there are twenty women for every man involved in witchcraft: 'the reason is easie, for as that sexe is frailer then man is, is it easier to be entrapped in these grosse snares of the Deuill, as was ouer well proued to be true, by the Serpents deceiuing of Eua at the beginning, which makes him the homelier with that sexe sensine ${ }^{17}$. Men in early modern England had superior roles in religion and government above that of subordinated women. That is why the alleged witches were seen to seek out alternative, occult forms of power to protect themselves and in order not to be violated by male authority.

The Witch of Edmonton dramatizes the conflicts of both social and demonic power in Edmonton near London. The double actions of The Witch of Edmonton achieve a structural unity in the play through the theme of the knowledge of both good and evil. Elizabeth Sawyer is seen as a product of her society rather than being anomalous in it as she points out that she lacks knowledge of witchcraft and is only taught by her neighbours unintentionally:

Some call me Witch;

And being ignorant of myself, they go

About to teach me how to be one; urging,

That my bad tongue (by their bad usage made so)

Forespeaks their Cattle, doth bewitch their corn,

Themselves, their Servants, and their babes at nurse. (II.i.8-15)

Through her speeches, Sawyer admits that she does not have any knowledge of good or evil on witchcraft but falls in witchcraft through temptations and her ignorance. Corbin and Sedge argue that through Sawyer's opening soliloquy, the audience is invited to 'respond to her with sympathy as a victim both of the devil's wiles and the social prejudices of the community in which she lives', and they argue that society predisposes the women to behave and feel in ways which expose them to the devil's temptation if it does not exactly make witches. ${ }^{18}$ I agree that Sawyer becomes a victim of both her familiar devildog and the Edmonton community. However, this evidence is enough to make Sawyer a witch since she makes a diabolical pact with the devil. She acknowledges that she has a bad tongue as a result of the ill-treatment of the villagers towards her. Her gender identity is constructed here as a witch while she blames her neighbours and says:

Still vex'd? still tortur'd? That Curmudgeon Banks

Is ground of all my scandal. I am shunn'd

And hated like a sickness: made a scorn

To all degrees and sexes. I have heard old Beldams

Talk of Familiars in the shape of Mice,

Rats, Ferrets, Weasels, and I wot not what,

That have appeared, and sucked, some say, their blood.

But by what means they came acquainted with them,

\footnotetext{
45-78 (p.77).

${ }^{17}$ King James I, Daemonologie (Edinburgh: 1597), II. V. 43-44.

${ }^{18}$ Corbin and Douglas, Three Jacobean Witchcraft Plays, pp. 24-25.
} 
I'm now ignorant: would some power good or bad, Instruct me which way I might be revenged Upon this Churl, I'd go out of my self And give this Fury leave to dwell within This ruined Cottage, ready to fall with age, Abjure all goodness: be at hate with prayer, And study Curses, Imprecations, Blasphemous speeches, Oaths, detested Oaths, Or any thing that's ill; so I might work Revenge upon this Miser, this black Cur That barks, and bites, and sucks the very blood Of me and of my credit. 'Tis all one

To be a Witch, as to be counted one. 120)

Vengeance, shame, ruin, light upon that Canker! (II.i.98-

In this context one can recognise a witch's speech rather than a speech by an ordinary woman. She has learned from others about beldams, familiars, sucking blood, and making a pact with the black Cur, Tom, which barks and bites in order to take revenge upon the 'Canker', Old Banks. Her speech shows the audience Mother Sawyer's understandable anger at being abused and beaten by her community. This leads her to desire to revenge herself by provoking her familiar to appear and make the pact with him. Herrington argues that The Witch of Edmonton is based on the recent trial of Mother Sawyer, but 'handling the old hag, her temptation and submission to the Devil, her traffic with her dog-familiar, and all the hard facts of her life as a social outcast, with a sympathy unknown to the trials, and seldom found anywhere in the literature of the age'. ${ }^{19}$ Mother Sawyer shows herself as ignorant in that she does not have any knowledge of this devilish power and how to achieve it. She is a victim of both the social prejudice of her village on one hand, and the devil on the other hand. Mother Sawyer goes to the gallows as she is convicted of witchcraft, as is Frank. Mother Sawyer is hanged by the end of the play like the witches of Lancashire.

The cases of both Elizabeth Sawyer, The Witch of Edmonton, and the seventeen witches of Lancashire, The Late Lancashire Witches, are approached by many early modern writers in their pamphlet publications and treaties, and dramatists in their plays. Briggs argues that witcheraft was treated seriously but still decoratively by the Elizabethan dramatists, as well as in later plays like, The Witch of Edmonton and The Late Lancashire Witches, but by the end of the century scepticism had gained ground, and witchcraft relapsed into a 'subject for pantomime'. ${ }^{20} \mathrm{I}$ agree with Briggs that witchcraft in Mother Bombie is treated lightly. After that, during the reign of King James I, Shakespeare, Jonson and Middleton treated witchcraft seriously and playfully at the same time. As the century

\footnotetext{
${ }^{19}$ H. W. Herrington, 'Witchcraft and Magic in the Elizabethan Drama', Journal of American Folklore, 32 (1919), 447-485 (p. 483).

${ }^{20}$ Katherine Mary Briggs, Pale Hecate's Team: an examination of the beliefs on Witchcraft and Magic among Shakespeare's Contemporaries and his Immediate Successors (London: Routledge \& K. Paul, 1962), p. 221.
}

went on, the idea of witchcraft in The Witch of Edmonton, and The late Lancashire Witches, tends to aim towards realism, and documented cases as their source is drawn from particular court trials. However, the plays written by the end of the century are more a subject for pantomime. For instance, The Lancashire Witches by Thomas Shadwell (1681), focuses more on the entertainment of the witches and the visual spectacle they create for the audience. Similarly, in Macbeth in Davenant's second Quarto (1674), the witch scenes were refashioned in order to offer a more spectacular version of witches instead of giving them a haggish and sinister look.

\section{Mother Bombie by John Lyly (1594)}

Witchcraft in the comedy of Mother Bombie is treated tolerantly compared to The Witch of Edmonton. Mother Bombie enjoys being a cunning woman and helping her community. According to the title page of the first quarto, the play is dated to 1594, 'Mother Bombie: As it was Sundrie times, plaid by the children of pawles', printed by Thomas Creede for Cuthbert Burby, 1594. ${ }^{21}$ However, Fleay dates Mother Bombie to $1588-9$ or possibly 1589$90 .{ }^{22}$ The second quarto is dated 1598. The 'uncourtly' Mother Bombie has been neglected among the critics compared to Lyly's other plays. One cannot find a definite source for this play. The play evokes all the aspects of contemporary sixteenth-century life in England and particularly the day-to-day affairs of the small town of Rochester in Kent. Mother Bombie is portrayed as an English cunning woman, marginalized and exiled from town society but still successful.

The plots are simply based on the idea that mischievous servants assist their young masters in marriage against their parents' wishes. The titular character denies that she is a witch, but a 'cunning woman'. The characters in the play consult her for advice and clairvoyance and she prophesizes the result of their situations. Like Hecate in The Witch, she appears not to have a significant effect on the characters, except when she convinces Vicinia to reveal her secret and this leads to the solving of the difficulties of the play. Her actions resolve the problem of those people who pursue love and happiness. The two lovers, Candius and Livia, the hero and heroine, are separated from each other by their fathers, who are only interested in making a profitable match. The two rich old men, Memphio and Stellio, want to arrange a marriage between their children Accius and Silena. Candius's father, Sperantus, wants his son to marry the rich Silena whereas Livia's father, Prisius, wants his daughter to marry the wealthy Accius. However, this foolish marriage is forestalled when Vicinia reveals that the two fools, Accius and Silena, are actually her own children whom she exchanged for Maestius and Serena, the old

\footnotetext{
${ }^{21}$ John Lyly, Mother Bombie, (London, 1594), title page.

${ }^{22}$ John Lyly, The Complete Works of John Lyly, ed. by R. Warwick Bond (Oxford: Clarendon Press, 1902), iii, p. 167.
} 
men's real offspring, years ago. The two lovers can now legitimately wed since they are not related. Mother Bombie tells Serena that she and Maestius 'shall be married to morrow hand in hand,/ By the laws of God, Nature, \& the land/ Your parents shall be glad, \& give you their hande' (III.i. 40-42). By the end of the play, the characters realize that Mother Bombie has spoken truly and they praise her for the good works she does to them.

The play was written about ten years after the publications of Scott's The Discovery of Witchcraft. Witch mania in England was not at its height during the performance of this play. Unlike Hecate's spell-binding classical witch, Bombie is more seen as a fortune-teller. Serena calls Mother Bombie an

old cunning woman, who can tell fortunes, expound dreames, tell of things that

be lost,

and deuine of accidents to come: she is called the good woman, who yet never did hurt (III.i.25-28).

The power of Mother Bombie as a white witch is detailed by Serena. White witches are seen to help society, as fortune-tellers and healers, and to bring good into the world. Bombie specifically defends herself against accusations of witchcraft:

SILENA. They saie you are a witch.

BOMBIE. They lie, I am a cunning woman. (II.iii.86-87)

Silena takes Bombie as a witch without understanding what she is being told. This suggests a reference to those cunning women who were accused of witchcraft and black magic in the trial records during Tudor times. However, Bombie insists on the distinction between these two types. Mother Bombie is again called one of the 'old hags' by Maestius when he says:

Content, sweet sister; and learne of me

hereafter, that these old sawes of such old hags,

are but false fires to leade one out of a plaine

path into a deep pit (III.i.56-60)

In this context, Lyly presents a societal accusation of witchcraft during the early Elizabethan period as well as Bombie's assertion of her innocence. What distinguishes her from the other alleged witches is that she does not use magical properties, such as herbs, spells, ointment, and incantation, for her mysterious gifts of divination. She rather can 'see' the future, reveal lost property and expound the meaning of dreams, and prophesy of accidents to occur. Bombie is consulted by Silena to give her clarification about her sexual status: 'I will know of the old woman whether I be a maid/ or no, and then, I must needs be a man' (II.iii.79-80). One can say that there is a joke here by Silena when she wants to know about her own femininity through Bombie. Bombie also is visited by Rixula: 'Nay, gammer, I pray you tell me who stole my spoone out of the buttrie?' (III.iv.147). In the final scene, Vicinia needs Bombie's assistance in recovery of lost children:

My heart throbbes, my ears tingle, my minde misgiues mee, since $i$ heare such muttering of marryages in Rochester. My conscience, which these eighteen yeeres hath beene frozen with

coniealed guiltynesse, beginnes nowe to thawe in open greiefe. But

I wil not acuuse my selfe till I see more danger: the good olde

Woman Mother Bombie shall trie her cunning vpon me: and if

I perciue my case is desperate by her, then wyll I rather preuent,

although with shame, then report too late, and be inexcusable. (V.ii. 1-8)

These characters visit Bombie to help and she does not take payment in return for her advice: 'I take no monie, but good words. Raile not if I tell true;/ if I doe not, reuenge' (III. iv. 182-183). It seems also she refuses payment for her services in III.i.47 and V.ii.1-27. Bombie is seen as a source of hope and comfort by the community of Kent even while witchcraft is suspected. Serena (III.i.25-28) and Memphio (V.iii.330-3320) take Bombie as a good wise woman who never hurts anyone, but Maestius suspects her supernatural power and distrusts her because of her haglike state (III.i.56-60).

Bombie does not pursue financial gain as she does not take money for her services but still does not live in her community. The only reason she stands aloof from the social group is because of her hag-like appearance, old age, and supernatural powers. For example, Maestius seeks her advice and responds to her while Bombie describes herself as:

\section{MOTHER BOMBIE. The dame of the house!}

MAESTIUS. She might haue said the beldam, for her face, and yeeres, and attire. (III.i.33-35)

'Beldam' means 'a loathsome old woman, a hag; a witch; a furious raging woman (without the notion of age), a virago'. ${ }^{23}$ The servants are also afraid because of Bombie's witch-like appearance that she will transfer them into nonhuman forms or apes:

HALFPENNY. Crosse your selues, look how she looks.

DROMIO. Marke her not, sheele turn vs all to Apes (III.iv. 86-87)

However, no transformation of human into animal takes place in the play. There is no devil familiar to aid Bombie and no witch accoutrements can be found in the play. Herrington argues that Mother Bombie is a portrait of an English type, a 'benevolent "wise woman", who, though accused of being a witch, denies it, and gives no evidence of trafficking with infernal powers'. ${ }^{24}$ She is not allied with the forces of evil like Erictho, the Weird Sister, Mother Sawyer and Hecate. She also does not deceive her clients through her fake prophetic powers like The Wise Woman of Hogsdon for her personal gain. Bombie is also not engaged in prostitution and the disposal of unwanted and

\footnotetext{
23 'Beldam', Oxford English Dictionary,

$<$ http://www.oed.com.ezproxy3.lib.le.ac.uk/view/Entry/17334?redirectedFrom

$=$ beldam\#footerWrapper $>$ [Accessed $7^{\text {th }}$ September 2013]

${ }^{24}$ Herrington, 'Witchcraft and Magic in the Elizabethan Drama', pp. 472-3.
} 
illegitimate babies like The Wise Woman of Hogsdon. Another difference between them is that Sawyer is not as social creature as Bombie and Heywood's the Wise Woman, but a social pariah. Although Bombie and the Wise Woman do not have Sabbath meeting, their own clients are enough to make them social.

\section{The Wise Woman of Hogsdon by Thomas Heywood (1604)}

Heywood treats witchcraft in his The Wise Woman of Hogsdon lightly. His witch, the Wise Woman, is comic and satirical and designed to suit the new fashion in contrast to his tragical witches in The Late Lancashire Witches. However, in both plays, Heywood presents a picture of some phase of contemporary English life. Not only do Mother Sawyer and Mother Bombie not make their entrances and exits through flying, but also The Wise Woman of Hogsdon does not fly. She simply enters and exits when she is summoned by her clients. The agreed year for the composition of The Wise Woman of Hogsdon is 1604 but it was not printed until 1638. It seems that The Wise Woman of Hogsdon was first performed by the Queen's Men at the Curtain theatre, the majority of the play's productions were likely made at the Red Bull, ${ }^{25}$ to which Queen Anne's Men repaired probably in $1605 .^{26}$ Heywood used the same Latin motto, 'Aut prodesse solent, aut Delectare', under his name in The Wise Woman of Hogsdon, and for his several other plays, which suggests the authenticity of his works. The complimentary epistle written by Samuel King to Heywood also suggests that the authorship of the play belongs to Thomas Heywood only. The play claims to have been successful and popular on the title page: 'As it hath been sundry times Acted with great Applause'. ${ }^{27}$ Here, I investigate the character of the Wise Woman and her activities as an alleged cunning woman, comparing it to the other plays I have already concentrated on.

The plot starts with the impostures of a fortune-teller. The Wise Woman does not resemble the classical nor Elizabethan black witch. As we have seen, Mother Bombie is white witch but the Wise Woman is a charlatan who pretends to be is a white witch for her personal gain. The titular woman pretends to have the ability to control the supernatural order. The play has three subplots, in which Second Luce, Luce (a goldsmith's daughter) and Sencer (a conceited gentleman) disguise themselves. Chartley leaves

\footnotetext{
${ }^{25}$ Red Bull was one of the oldest and popular theatres in London, originally was an inn yard and converted into theatre during the reign of Elizabeth. Thomas Heywood, The Best Plays of the Old Dramatists: Thomas Heywood, ed. by A. Wilson Verity; with an Introduction, ed. by J. Addington Symonds (London: Vizetelly, 1888), p. xxxiii.

${ }^{26}$ Thomas Heywood, A Critical Edition of Heywood's The Wise Woman of Hogsdon, ed. Michael H. Leonard (New York and London: Garland, 1980), p. 37

${ }^{27}$ Thomas Heywood, The Wise Woman of Hogsdon (London, 1638), p. frontispiece
}

his betrothed Luce and comes to London where he is married secretly to another woman of the same name. However, Luce follows him to London and by means of a scheme assisted by the Wise Woman, Chartley's secret marriage to the second Luce takes place in the dark. The intriguer characters who have a role in the scheming are the Wise Woman (chief intriguer), Second Luce, Luce, Chartley (a wild-headed gentleman), and Sencer. The Wise Woman of Hogsdon is very well managed despite having complications in its plot between the two Luces, a young Lady and a young Chartley. Luce and the Wise Woman have a very good friendship. Lucy's father, Sir Harry (a knight), portrays the figure of a wise old man, and Sir Boniface is an ignorant pedant or schoolmaster. The pair of lovers are in complicated relationships: Gratiana (Sir Harry's daughter) and Sencer; Luce is married to Boyster (a blunt fellow) but then Chartely restored to her. Second Luce is disguised as Jack, the wise woman's boy servant. By the end of the play the three couples, Gratiana and Sencer, Luce and Boyster, Second Luce and Chartley all get married.

The Wise Woman has a low status in her community and is surrounded by credulous men and women, by which Heywood portrays both the virtues and the follies of English life. Gibbons argues that Heywood in writing The Wise Woman of Hogsdon 'was capable not only of satirizing the typically ineffectual civil authorities, gullible or venal citizens, and wily rogues of his day but also of sustained literary reflection on the social challenges posted by the dynamic conditions of urban life in the seventeenth century'. ${ }^{28}$ The Wise Woman of Hogsdon is a comedy of English life, and, unlike some of the other plays discussed earlier, there are no murders and suicides. Heywood depicts an English domestic life and in particular the picture of the surface of London life. There is not a direct source for the plots of The Wise Woman of Hogsdon. Cromwell argues that the play is a clever comedy of intrigue, 'the centre of the action being the "wise woman" of Hogsdon (Hoxton), a charlatan whose prototype may well have been an actual London figure'. ${ }^{29}$ Sawyer lives in Edmonton and the Wise Woman lives in Hoxton, both located in the suburbs of London. Mother Bombie resides in Rochester in Kent. Cunning women, witches, gamblers, and prostitutes live in the suburbs as it is the place free of city jurisdiction for their licentious behaviour. This is also why most of the theatres, gaming houses, pools and yards, and brothels were outside the jurisdiction of London. The three plays have an urban setting and thus the dramatists focus on middle- and lower-class concerns including witches, servants, clown, fool and cunning women. The play also shows the role of the theatre in shaping urban life through its manifestations of the changing spaces of the suburbs of London in the early modern era. For instance, the problems of the

\footnotetext{
${ }^{28}$ Daniel R. Gibbons, 'Thomas Heywood in the House of the Wise Woman', Studies in English Literature, 1500-1900, 49 (2009), 391-416 (p. 392).

${ }^{29}$ Otelia Cromwell, Thomas Heywood: A Study in the Elizabethan Drama of Everyday Life ([Hamden, Conn.]: Archon Books, 1969 [c1928]), p. 58.
} 
community's sexual and social economy get solved in the house of the Wise Woman. The cunning women, Bombie and the Wise Woman, occupy a central position in urban life. Her abode becomes a familiar and local place for her clients' illegitimate desires.

The Wise Woman assures the audience that she does not make any pact with the devil. The lower-class Wise Woman pretends that she serves her community in several ways by use of her power, such as finding lost objects, seeing the future, and diagnosing illness, in order to make her living:

Let me see, how many trades have I to live by? First, I am a wise-woman and a fortune-teller, and under that I deal in physic and fore-speaking, in palmistry and recovering of things lost. Next, I undertake to cure mad folks. Then I keep gentlewomen lodgers, to furnish such chambers as I let out by the night. Then I am provided for bringing young wenches to bed. And, for a need, you see I can play the match-maker" (III.i.993-1000). ${ }^{30}$

She assures the audience that she is only a cunning woman by giving a resume of her different skills. The Wise Woman does not have a familiar spirit or a devil to aid her in her trades. The Wise Woman and Bombie do not perform Maleficium: since their intention is to help their surroundings, not to lame and kill children, blighting stock and crops.

The Wise Woman mentions the victim witches who were hanged because they had talent in different objects:

You have heard of Mother Bomby; and then there is one Hatfield in Pepper Alley, he doth pretty well for a thing that's lost. There's another in Coleharbour, that's skilled in the planets. Mother Struton, in Golden Lane, is for fore-speaking; Mother Philips, of the Bankside, for the weakness of the back; and then there's a very reverend matron on Clerknwell Green; good at many things. Mistress Mary on the Bankside is for 'recting a figure; and one (what do you call her?) in Westminister, that practiseth the book and the key, and the sieve and the shears: and all do well, according to their talent. For myself, let the world speak. Hark you, my friend, you shall take. [She whispers. (II.i) ${ }^{31}$

The Wise Woman lists numerous traditional witches or disreputable practitioners with their specialists. Andreadis notes that the name 'Bombus' is listed in the 'Dictionarium Historicum \& Poeticum' appended to Thomas Cooper's Thesaurus Linguae Romanae \& Britannicae (1565), with the gloss, 'The name of a certain diuinour', and that a further seven references to a (Mother) Bungie, Bumbye, or Bumby occur in the course of the later sixteenth and early seventeenth centuries. ${ }^{32}$ Reginald Scot in The Discoverie of Witchcraft (1584) mentioned Mother Bungie of Rochester

\footnotetext{
${ }^{30}$ Heywood, A Critical Edition of Heywood's The Wise Woman of Hogsdon, ed. by Michael H. Leonard, pp. 143-144.

${ }^{31}$ Thomas Heywood, The Best Plays of the Old Dramatists: Thomas Heywood, ed. by A. Wilson Verity; with an Introduction, ed. by J. Addington Symonds, p. 266.

${ }^{32}$ Quoted in John Lyly, Mother Bombie, ed. by Leah Scragg (Manchester: Manchester University Press, 2010), p. 13.
}

in Kent, as an example of witches who were charlatans and did not have any supernatural powers. Lyly has presumably based his Mother Bombie on his knowledge of Scot's Bungie. Here, Heywood makes a joke based on audience's recognition of Mother Bombie. Mother Bombie is also referenced again in The Witch of Edmonton when Old Bank calls Sawyer: 'You see your work, Mother Bumby (IV. i). ${ }^{33}$ The Wise Woman of Hogsdon was written ten years after Mother Bombie but The Witch of Edmonton twenty seven years. This shows the continuity of witchcraft on stage from the Tudor period until the end of Jacobean times, from the time that witch mania in England was on the rise until the time that it was at its greatest height. Alternatively, it might show at least a lot of stage repertories. The fiction of Mother Bombie becomes a real person to the audience through the allusion made in both plays. Here, there is a tendency to invite sympathy for Mother Bombie and her fellow witches by drawing attention to the misuse of the term 'witch' as an insult. Regarding her other contemporaries, the Wise Woman lists them and names the fields they specialize in. This context shows also the examples of supernatural arts in which the Jacobean witches specialized and for which they were consulted, such as casting waters, locating lost properties, the planets, prophesying, weaknesses of the back, acting as a general practitioner, and 'recting a figure' or astrology. Middleton, in The Witch, also casts his witches into different supernatural gifts: for instance, Hecate is skilled in bringing about the failure of marriage between the characters through causing impotence in man or infertility in woman and also has the power to fly at night with her familiar; Hoppo acts maleficium (kills the cattle and destroy orchards and etc.); Stadlin raises storms to wreck ships and a house. The Weird Sisters of Macbeth are skilled in prophesying, Faustus in astrology, Sawyer in maleficium and Erictho has skills in the weather, the heaven and the earth.

In contrast to the previous witches, the Wise Woman pretends to be skilled in fore-speaking, palmistry and curing diseases. However, it is not very clear to Second Luce how the Wise Woman can tell the future:

SECOND LUCE, 'Tis strange the ignorant should be thus fooled!

What can this witch, this wizard, or old trot,

Do by enchantment, or by magic spell?

Such as profess that art should be deep scholars.

What reading can this simple woman have?

'Tis probably gross foolery. [Exit Countryman. (II.i) ${ }^{34}$

Second Luce, disguised in boy's clothes, has come to London to find out about her wayward love. She disbelieves the Wise Woman's skill and asks if she gains her mysterious power through enchantment or a magic spell. She discovers the fraud once she finds a job as the servant of the Wise Woman. The Wise woman gains her

\footnotetext{
${ }^{33}$ Thomas Dekker, John Ford, William Rowley, The Witch of Edmonton (1658), p. 45 .

34 Thomas Heywood, The Best Plays of the Old Dramatists, p. 266.
} 
supernatural power only through tricks and illusions. Reginald Scot, in The Discovery of Witchcraft, also argues that so-called cunning woman, conjurers, exorcists, witches, and other 'jugglers' were simply charlatans who gained their power by tricks, illusions, and the artful leading on of their clients. The Wise Woman resides in Hogsdon (Hoxton), the suburb of London, and is a fortune-teller for her neighbourhood, women and men. She is not loved by her customers. The Wise Woman is called witch, wizard and old trot by Second Luce. She is again called a 'witch', 'hag', and 'beldam' when she is confronted by Young Chartley:

See, here she is. How now, witch! How now, hag! How now, beldam! You are the wise woman, are you? And have wit to keep yourself warm enough, I warrant you. WISE WOMAN. Out, thou knave!

SECOND LUCE. And will these wild oats never be sown? [Aside.

YOUNG CHARTLEY. You enchantress, sorceress, shedevil! You Madam Hecate, Lay Proserpine!

you are too old, you hag, now, for conjuring up spirits yourself; but you keep pretty young witches under your roof, that can do that.

WISE WOMAN. I or my family conjure up any spirit! I defy thee, thou young hare-brained-(II. i)

Young Chartley perhaps teasing the old actor who performs the role of the Wise Woman. This is perhaps because an older actor plays the part of the Wise Woman and thus cannot have a role as a romantic female. If she wanted to be sexually attractive, her role should have been played by a soft-voiced and complexioned young boy actor. The Wise Woman appears as a conventional rogue. She is entertaining and gets a reputation for accomplishing wonders. The Wise Woman's prophetic power is based on the knowledge given by the credulity of her clients. In other words, she performs the tricks through sheer knavery and the disclosures of her costomers whom she visits before she predicts their wonders. For instance, she repeats back to them the information that she has already received by asking her clients about their problems, creating the illusion that she earned this knowledge through the art of magic:

WISE WOMAN. And where doth the paine hold her most? COUNTRYMAN. Marry at her heart forsooth.

WISE WOMAN. Ey, at her heart, she hath a griping at her heart.

COUNTRYMAN. You have hit it right.

WISE WOMAN. Nay, I can see so much in Urine. (II.i)

The play also satirizes the gullibility and superstition of simple-minded folk who resort to the wise woman for their problems, and do not realise that they are being cheated. However, the Wise Woman admits that she does not have any contact with the devil when she practices her supernatural power. Boyster enters and asks:

Canst conjure?

WISE-WOMAN. Oh, that's a foul word! But I can tell you your fortune, as they say; I have some little skill in palmistry, but never had to do with the devil. BOYSTER. And had the devil never anything to do with thee? Thou look'st somewhat like his dam. Look on me: canst tell what I ail? (II. i)

Once again, sexual innuendo can be found here in the response of a man to a cunning woman, a further sign of the association between sexual immorality and their social position.

The Wise Woman gains her reputation not through magical power, but through manipulation of the fake skills she claims for herself. Thus, her identity as a witch is produced by her customers. In contrast to Mother Sawyer, she does not make any pact with the devil and does not threaten anyone, nor does she have a familiar devil to make a pact with and sell her blood. No coven of witches is depicted in each of The Witch of Edmonton, Mother Bombie and The Wise Woman of Hogsdon. Albert Tricomi argues that 'although exposed as a charlatan and a bawd of sorts, the Wise Woman resolves, in socially productive ways and despite her marginalised status, problems ensuing from illegitimate births and predatory gallants'. ${ }^{35}$ In spite of being a fraud, the Wise Woman is a source of comfort and reassurance for the Hogsdon community as she has power in disposing of the illegitimate babies and facilitates for those who pursue love. Midwifery was also practised by the cunning or wise woman. Heywood presents satirically the Wise Woman only as a charlatan and no more than a fraud. This suggests that all the so-called witches are as false and fraudulent as she. The Wise Woman of Hogsdon is more theatrical, Helgerson argues, "where the charlatan wise woman is allowed to preside over the play's comic denouement and where a gentlewoman in boy's clothing successfully controls the action and achieves her desire'. ${ }^{36}$ In other words, 'women employ theatrical practices to fulfil their desires'. ${ }^{37}$ For instance, the Wise Woman has so many books whereas she can neither write nor read, but pretends to read in order to fool her clients: 'for to be ignorant, and seem ignorant, what greater folly?' (III.i.885-886). Therefore, she pretends to be a cunning woman for her own personal gain.

\section{Genre and Stage Directions of these Three Plays}

The play is full of sexual innuendo and farcical wordplay and several elements of archetypal pantomime. Withholding essential information from the audience, intrigue and deception by cross-dressing are the common

\footnotetext{
${ }^{35}$ Albert H. Tricomi, review of 'The Stage and Social Struggle in Early Modern England', ed. by Jean E. Howard, Journal of English and Germanic Philology, 95 (1996), 113-115 (p. 115).

${ }^{36}$ Richard Helgerson, review of 'The Stage and Social Struggle in Early Modern England', ed. by Jean E. Howard, Comparative Literature, 48 (1996), 383-385 (p. 384).

${ }^{37}$ Theodore B. Leinwand, review of 'The Stage and Social Struggle in Early Modern England', ed. by Jean E. Howard, Shakespeare Quarterly, 47 (1996), 204-206 (p. 205).
} 
dramatic devices that Heywood used for the plots of his comedy. One cannot find supernatural accoutrements in the play, such as flying witches, making a diabolical pact with the devil, the transformation of humans into animals and having a devil on stage. There are no classical motifs of witchcraft as elements of this comedy, but only simple intrigue and cross-dressing. There is also no evidence of the use of stage spectacle such as 'Thunder and Lightening', in comparison to Hecate, and Mother Bombie, when she enters. She simply enters and exits. No stage directions call for her to fly: the Wise Woman appears on stage four times (in II. i, III. i, V. ii, and V. iv) and the stage direction each time reads as: Enter the Wise-woman. ${ }^{38}$ The stage directions make clear that she is entering on foot rather than sitting on her stool when summoned.

Similarly, Lyly's Bombie does not fly, like the Continental witches. In the early editions, Mother Bombie simply enters when Silena crosses to her house and calls her (II.iii.91):

\section{Enter Mother Bombie ${ }^{39}$}

Bombie also simply enters when summoned in the other early editions. ${ }^{40}$ However, in the Revels edition, Leah Scragg assumes that, as the early editions imply, Mother Bombie is already seated upon her stool as her door is opened, witch-like in both posture and attire, rather than simply entering when summoned. ${ }^{41}$ According to Scragg the stage direction reads (II.iii.93):

[The door of the house opens to disclose]

Mother BOMBIE [sitting on a stool]. ${ }^{42}$

This is because in the following lines Bombie asks Silena to hold up her hand but Silena holds it up too high for her to inspect. Bombie then says 'not so high'. This implies that Bombie is already seated on her stool rather than entering on foot. The stage direction again reads as [The door opens to MOTHER BOMBIE seated on her stool] in (III.iv.84) when she is visited by the servants, and when Vicinia summons her for the recovery of the lost children in (V.ii.11). However, such an interpretation of the stage business ignores the clear direction in the early editions that Bombie simply enters in the mentioned scene.

There is also no scene or stage direction to call for flight of Mother Sawyer. She simply enters and exits the stage, in what we can assume to be an unspectacular fashion. So, witch's flight as an element of comedy cannot be found in The Witch of Edmonton. The play offers a dramatic style of tragicomedy which is different from the tragicomedy of Middleton's The Witch. Flight is not one of Sawyer's activities as it is for Hecate. The flight of Hecate with Malkin is a comic part of the play, but this cannot be found here. Sawyer is in line with Bombie and the Wise Woman

\footnotetext{
${ }^{38}$ Thomas Heywood, The Wise Woman of Hogsdon (London, 1638); Thomas Heywood, A Critical Edition of Heywood's The Wise Woman of Hogsdon, and Thomas Heywood, The Best Plays of the Old Dramatists.

${ }^{39}$ John Lyly, Mother Bombie, (London, 1594), no page number is given.

${ }^{40}$ Lyly, The Complete Works of John Lyly, p. 91.

${ }^{41}$ John Lyly, Mother Bombie, ed. by Leah Scragg, p. 38.

${ }^{42}$ Ibid., p. 104.
}

only in stage directions when she makes her entrances and exits. As a traditional English witch, Sawyer simply enters in early editions and modern editions. She appears four times on stage in (II.i), (IV.i), (V.i), and (V.iii), stage direction in these scenes reads as: 'Enter Elizabeth Sawyer'. ${ }^{43}$ It is not very clear whether she stands up or is seated when she is summoned by her customers.

Blackfriars presented witchcraft in tragicomic modes in which contemporary writers could engage and relate these texts to contemporary issues. The Witch of Edmonton is a tragicomedy-type whereas both Mother Bombie and The Wise Woman of Hogsdon are comedy. Witchcraft has been treated lightly in them. Mother Bombie and the Wise Woman are comic and satirical and designed to suit the new fashion, compared to tragical witches in The Witch of Edmonton and The Late Lancashire Witches. The witch scenes in Macbeth (1606), The Witch of Edmonton (1621), and The Late Lancashire Witches (1634) comprise the tragic part of play while the witch scenes in Mother Bombie (1590), The Wise Woman of Hogsdon (1604), Sophonisba (1605-1606), The Masque of Queens (1609), and The Witch (1609-1616), comprise the comic part of the play. All these plays offer us a picture of the English witch of that time through the aspects of her practice. This tells us that the forms of witchcraft treated in the late Elizabethan times (Mother Bombie and The Wise Woman of Hogsdon), and Jacobean times (The Witch of Edmonton) all differ subtly according to their historical context. The playwrights do not use Continental features of witchcraft in these mentioned plays such as aerial journey of witches during the night. Bombie and the Wise Woman survive by the end of the play, but not Mother Sawyer. Witchcraft in The Witch of Edmonton is more historically situated and the witch character is fated to die as she is a threat to her community. However, Bombie and the Wise Woman survive because Bombie uses her mysterious power not to harm, but to help. The Wise Woman also pretends to have prophetic power, but she does not, and still survives until the end of the play.

Witchcraft in The Witch of Edmonton is used as a subject of pantomime through the use of a familiar on stage. For instance, the transformation of a human being into an animal, Sawyer's familiar is a devil in the shape of a dog. The dog is black which symbolizes evil and temptations, like Faustus's dog, and Hecate's Malkin in the cat's costume. The familiar dog helps Sawyer by killing Old Banks's cattle. The performance of the dog on stage is considered as a comic element of the play. Even so, the spectacle of 'thunder and lightning' accompanies the dog when he sucks Sawyer's arm: '[Sucks her arm, thunder and lightning,. ${ }^{44}$ With the help of her dog, Sawyer causes her neighbour, Ann Ratcliffe (Old Ratcliffe's wife), to go insane and kill herself. Sawyer and Tom are also executed at the end. However, death is mentioned from the very

\footnotetext{
${ }^{43}$ Thomas Dekker, John Ford, and William Rowley, The Witch of Edmonton (1658); Dekker, The Witch of Edmonton: A Critical Editions; Corbin and Douglas, Three Jacobean Witchcraft Plays.

${ }^{44}$ Dekker, Ford, and Rowley, The Witch of Edmonton (1658), p. 18.
} 
beginning of the play, but this is not enough to override the comic elements of the play.

The genre of Mother Bombie is based on Roman models. The play, as a domestication of classical comedy in Roman style, is resolved by a classical device. The mayor of the provincial town involves himself in the events instead of a deity or monarch to solve the problems of the play. As in the tradition of early 'classical' comedies, Lyly uses each of the Hackneyman, Scrivener, Sergeant and Fiddlers of Kent in order to offer a more homely local taste to the play. However, the recovery of lost children and the confirmation of the identity of the characters which the plot is based on are drawn from Roman drama, especially Terence. The characters have Greek names, with the exception of Mother Bombie and one servant who have English provincial town names. One can say that this comedy includes classical figures, English landscape, sixteenth-century English cunning women and servants. As a work of farce, the play is full of love, tricks and masked identity. Bombie portrays a major role in this comic play and she manipulates the love plot. Each of the tricks and disguises are farcical elements of comedy. Besides these comical elements, four songs are sung by the simpletons, servants and fiddlers in (II.ii.164-183, III.iii1-14, III.iv.42-61, and V.iii.64-84), but there is not any witch feasting and rite. No devil appears to offer a comic spectacle to the audience. Lyly shapes the urban life of Rochester through Mother Bombie as an early manifestation of a later fashion for witches on stage.

\section{References}

[1] Ashley, Leonard R.N., review of 'The Witch of Edmonton: A Critical Edition. Renaissance Drama Series', ed. by Etta Soiref Onat and Stephen Orgel, Bibliotheque d'humanisme et Renaissance, 2 (1982), 476-479

[2] Atkinson, David, 'Moral Knowledge and the Double Action in The Witch of Edmonton', Studies in English Literature, 25 (1985), 419-437

[3] Briggs, Katherine Mary, Pale Hecate's Team: an examination of the beliefs on Witchcraft and Magic among Shakespeare's Contemporaries and his Immediate Successors (London: Routledge \& K. Paul, 1962)

[4] Corbin, Peter and Douglas Sedge, Three Jacobean Witchcraft Plays: The Tragedy of Sophonisba, The Witch, and The Witch of Edmonton (Manchester \& New York: Manchester University Press, 1986)

[5] Cromwell, Otelia, Thomas Heywood: A Study in the Elizabethan Drama of Everyday Life ([Hamden, Conn.]: Archon Books, 1969 [c1928])

[6] Dekker, Thomas, Ford, John, and Rowley, William, The Witch of Edmonton (London, 1658)

[7] The Dramatic Works of Thomas Dekker, ed. by Fredson Bowers (Cambridge: The Syndics of the Cambridge University Press, 1958), iii

[8] The Witch of Edmonton: A Critical Edition, ed. by Etta Soiref Onat (New York: Garland, 1980)
[9] Ford, John, The Dramatic Works of John Ford: in two volumes, with notes critical and explanatory, ed. by William Gifford, 2 vols (London, 1827), ii

[10] The Dramatic Works of John Ford: with an introduction and explanatory notes, ed. by Henry Weber, 2 vols (London, 1811)

[11] Gibbons, Daniel R., 'Thomas Heywood in the House of the Wise Woman', Studies in English Literature, 1500-1900, 49 (2009), 391-416

[12] Helgerson, Richard, review of 'The Stage and Social Struggle in Early Modern England', ed. by Jean E. Howard, Comparative Literature, 48 (1996), 383-385

[13] Herrington, H. W., 'Witchcraft and Magic in the Elizabethan Drama', Journal of American Folklore, 32 (1919), 447-485

[14] Heywood, Thomas, The Wise Woman of Hogsdon (London, 1638)

[15] The Dramatic Works of Thomas Heywood, 6 vols (New York: Russell \& Russell, 1964)

[16] A Critical Edition of Heywood's The Wise Woman of Hogsdon, ed. by Michael H. Leonard (New York and London: Garland, 1980)

[17] The Best Plays of the Old Dramatists: Thomas Heywood, ed. by A. Wilson Verity; with an Introduction, ed. by J. Addington Symonds (London: Vizetelly, 1888)

[18] Holmes, Clive, 'Women: Witnesses and Witches', Past \& Present, 140 (1993), 45-78

[19] King James VI, Daemonologie (Edinburgh: 1597)

[20] Daemonologie in Forme of Dialogve, Diuided into Three Books (London: Arnold Hatfield, 1603)

[21] Leinwand, Theodore B., review of 'The Stage and Social Struggle in Early Modern England', ed. by Jean E. Howard, Shakespeare Quarterly, 47 (1996), 204-206

[22] Lyly, John, Mother Bombie (London, 1594)

[23] The Complete Works of John Lyly, ed. by R. Warwick Bond (Oxford: Clarendon Press, 1902)

[24] Mother Bombie, ed. by Leah Scragg (Manchester: Manchester University Press, 2010)

[25] Purkiss, Diane, The Witch in History: Early Modern and twentieth-Century Representations (London and New York: Routledge, 1996)

[26] Sawyer, Ronald C., 'Strangely Handled in All Her Lyms': Witchcraft and Healing in Jacobean England', Journal of Social History, 22 (1989), 461-485

[27] Scot, Reginald, Scot's Discovery of Witchcraft (London, 1654)

[28] Sharpe, James, 'The Debate on Witchcraft', in A Companion to English Renaissance Literature and Culture, ed. by Michael Hattaway (Oxford: Blackwell, 2003), pp. 653-661

[29] Thomas, Keith, Religion and The Decline of Magic: Studies in Popular Beliefs in Sixteenth and Seventeenth-Century England (London: Penguin, 1971) 
[30] Tricomi, Albert H., review of 'The Stage and Social Struggle in Early Modern England', ed. by Jean E. Howard, Journal of English and Germanic Philology, 95 (1996), 113115
[31] 'Beldam', Oxford English Dictionary, $<$ http://www.oed.com.ezproxy3.lib.le.ac.uk/view/Entry/173 34? redirectedFrom=beldam\#footerWrapper $>\left[\right.$ Accessed $7^{\text {th }}$ September 2013] 